Acta Theriologica 43 (4): 391-408, 1998.

PL ISSN 0001-7051

\title{
Maternal behaviour and juvenile dispersal in the Eurasian lynx
}

\author{
Krzysztof SCHMIDT
}

\begin{abstract}
Schmidt K. 1998. Maternal behaviour and juvenile dispersal in the Eurasian lynx. Acta Theriologica 43: 391-408.

Lynx Lynx lynx maternal behaviour and dispersal pattern were studied by radio-telemetry in the Białowieża Primeval Forest, E Poland from 1992-1995. From June-July, 2 females with kittens used 1-4 dens per month, for 5 to 33 days each. Consecutively used dens were $1-3 \mathrm{~km}$ apart and were located in inaccessible places. Female movements were concentrated around the den at this time. Mothers left their kittens and returned to them, on average, 3 times per day. Mean time of female's absence from the den was $4 \mathrm{~h} 20 \mathrm{~min}$. Mean den attendance averaged 4 hours. In August, kittens began to accompany their mother. At this time, each den was used for $2-3$ days only and the distances between consecutive dens were $0.5-2 \mathrm{~km}$. Dens were situated in places where a female killed large prey. In August, a female spent an average of $12 \mathrm{~h} 50 \mathrm{~min}$ with kittens, alternating with 4-h of absence. Subadults dispersed at 9-11 months of age, immediately after separation from their mothers. Four subadult males dispersed for $11,39,62$ and $129 \mathrm{~km}$ from their natal ranges. Two subadult females dispersed for 5 and $9 \mathrm{~km}$. Lynx that moved the farthest distances covered most of their routes during the first two months of dispersal, when they moved 20-32 km/month, compared to 3-11 km/month in the later period. Distant emigrations of two adult lynx ( $55 \mathrm{~km}$ by a male and $120 \mathrm{~km}$ by a female) were also recorded. Directions and routes of lynx dispersal and emigration were related to the contemporary distribution and availability of woodlands and forest corridors.
\end{abstract}

Mammal Research Institute, Polish Academy of Sciences, 17-230 Białowieża, Poland

Key words: lynx, dispersal, maternal behaviour, forest corridors

\section{Introduction}

Reproductive rate of Eurasian lynx Lynx lynx (Linnaeus, 1758) is low, as in most other felids (Kitchener 1991). Jędrzejewski et al. (1996) found that in Białowieża Primeval Forest, the mean number of kittens per reproducing female was 3.3 at the birth time and 1.6 at the time of juvenile dispersal (when 9 months old). They also reported that the highest mortality of young lynx occurred between 3-4 month of their life. The causes of juvenile mortality in lynx are unknown but may include predation and starvation. In cheetah, Acinonyx jubatus, the risk of cub mortality due to predation was high and influenced the pattern of maternal care (Laurenson 1994). Sokolov et al. (1994) described cases of intraspecific aggression among small lynx siblings, leading to death of poorly developed kittens. 
So far, there is no information on the behaviour of free living female lynx raising kittens. One can suppose that females adjust their behaviour to maximally protect the kittens during the stage of their high vulnerability to predation.

Except for information provided by Haller and Breitenmoser (1986) and Breitenmoser et al. (1993a) concerning a reintroduced population of lynx, there are no data on dispersal of this felid. In most European countries, the lynx no longer occurs due to deliberate extermination by humans and shrinkage of suitable habitats (Breitenmoser and Breitenmoser-Würsten 1990). Although this species has recently been reintroduced elsewhere, this experiment has met numerous obstacles (Jackson 1994, Böer et al. 1995). Therefore, it is important to measure the potential of lynx to recolonize habitat through natural dispersal.

The objectives of this paper were to describe observations on: (1) the behaviour of female lynx with young, and (2) dispersal behaviour and routes of juvenile lynx.

\section{Study area}

This study was conducted in the Polish part of Białowieża Primeval Forest (BPF, $580 \mathrm{~km}^{2}$ ), located on the Polish and Belarussian borderland $\left(52^{\circ} 30^{\prime}-53^{\circ} \mathrm{N}, 23^{\circ} 30^{\prime}-24^{\circ} 15^{\prime} \mathrm{E}\right)$. BPF is the best preserved deciduous and mixed lowland forest in Europe (Faliński 1986). In contrast to other European woodlands, BPF is mostly continuous with only a few settlements. Forests of BPF are dominated by spruce Picea abies, pine Pinus silvestris, oak Quercus robur, lime Tilia cordata, hornbeam Carpinus betulus, black alder Alnus glutinosa and ash Fraxinus excelsior. About one-third of the BPF's area was covered with pristine oldgrowth forest of natural origin. Remaining part of the forest was replanted. During the study period, $92 \%$ of BPF was managed by state forestry (commercially logged since 1915) and $8 \%$ was strictly protected as Białowieża National Park (BNP) since 1921. A more detailed description of BPF is given in Schmidt et al. (1997).

Radio-tracking of dispersing lynx was also done in Knyszyn Forest (KF, $790 \mathrm{~km}^{2}, 53^{\circ}-53^{\circ} 30^{\prime} \mathrm{N}$, $23^{\circ}-23^{\circ} 45^{\prime} \mathrm{E}$ ), located in NE Poland, and separated from BPF by a farmland-forest landscape. KF was dominated by pine and spruce stands mostly of secondary origin (Zaręba 1986). Another large forest tract located south-easterly of BPF was Mielnik Forest $\left(400 \mathrm{~km}^{2}, 52^{\circ} 15^{\prime}-52^{\circ} 30^{\circ} \mathrm{N}, 23^{\circ}-23^{\circ} 15^{\prime} \mathrm{E}\right)$, which was dominated with secondary stands of pine, interspersed with and surrounded by the mosaic of farmland and woodlots (Zaręba 1986). On the east, BPF adjoins Ruzhana Forest (Belarus, $52^{\circ} 30^{\prime}-52^{\circ} 50^{\prime} \mathrm{N}$, $24^{\circ} 30^{\prime}-25^{\circ} \mathrm{E}$ ), which forms a $9-20 \mathrm{~km}$ wide forest corridor to other vast forests of Belarus.

\section{Material and methods}

From a total of 18 individuals radio-tracked in 1991-1995, five adult lynx (1 male, 4 females) and six young ( 4 males and 2 females) yielded information on maternal behaviour and dispersal (Appendix I). Lynx were captured with footsnare traps and a double-door box trap in the Polish part of BPF, and were radio-collared. Radio-locations were collected from the ground using a car (details on radio-collaring and radio-tracking procedures in Schmidt et al. 1997). Lynx were searched for 5-7 times per week. In addition, sessions covering 1-5-days of continuous tracking were conducted each month on individual lynx. Locations were taken every 30 minutes during continuous tracking. Additional records of lynx movements were obtained from cases of poaching, recovery of dead lynx, and visual observations of alive animals. 
Suspected parturition dates and den sites used in June-July, were determined on the basis of detailed observations of female movements. In most cases it was not sure if the den was the place where kittens were born. Therefore, the term "den" referred to any temporary sites repeatedly used by females with kittens for several days, including those sites where kittens were left with the kill. To avoid disturbing a female, I took bearings from a distance of about $100 \mathrm{~m}$ away from the female and checked those sites after the female had moved to the next den. Except for one case when a dead kitten was found, no signs of lynx presence were recorded in the presumed den sites in June-July. Thus, because of error associated with radio-telemetry, descriptions of the suspected den sites represent an approximate area of $50 \mathrm{~m}^{2}$.

In August, remnants of ungulate prey were found in most of the places where the female and kittens stayed $\geq 2$ days. Such places were considered kittens' dens, because a female with young usually moved from one kill to another. Kittens probably stayed near the kill site until it was consumed.

From November 1994 through April 1995, the dispersion of a lynx family was measured for a female Sonia and 2 of her 3 kittens through simultaneous radio-tracking (see Appendix I). The proportion of time a female spent with her kittens was calculated only for continuous sessions of radio-tracking. Additionally, percentages of daytime and night locations when a female was found with kittens were calculated for all radio-locations. The minimum daily distance (MDD) moved by a female was estimated on 26 days of continuous radio-tracking conducted in February, June-August, and November. The MDD was calculated as a sum of straight-line distances between consecutive locations taken at 1 -hour intervals.

In the cases of dispersing juveniles, the dispersal distance and its increase with time were measured between the last location of a kitten with its mother (or the last location of a kitten in its natal range) and the farthest locations in the consecutive months. The rate of dispersal was estimated by measuring the distances between the farthest locations in consecutive months. Home ranges of subadult lynx were estimated by $100 \%$ Minimum Convex Polygon. The term "dispersal" referred to juveniles, while "emigration" to adults leaving their established territories.

\section{Results}

\section{Behaviour of females with kittens}

Parturition in 3 radio-collared females occurred between 4 and 24 May and the litters consisted of 3,2 and 1 kittens. The single kitten was found dead from unknown reasons, when 7 days old. For two months after parturition (May-June) females movements were within $<3 \mathrm{~km}$ of the den (Fig. 1). In later months females moved more widely and showed no measurable center of activity. From September through March, females with kittens were visiting parts of their home ranges separated by $15-\mathrm{km}$ straight-line distance (Fig. 1).

In June and July, females used 1-4 dens per month, from 5 to 33 days (Fig. 2, Table 1). The distance between consecutive dens varied from 1.1 to $3.3 \mathrm{~km}$. Female Sonia, whose dens were near the state border (low human activity), used them longer than female Natasza who lived in the exploited forests (higher human activity). In August, female (only Sonia observed) utilized at least 7 dens and stayed there no longer than 2-3 days, significantly shorter than in the preceding period (Mann-Whitney $U$-test, $U=49.0, p<0.001$ ). Subsequently occupied sites were $0.5-2.0 \mathrm{~km}$ away, similar to June-July (Mann-Whitney $U$-test, $U=22.0$, 


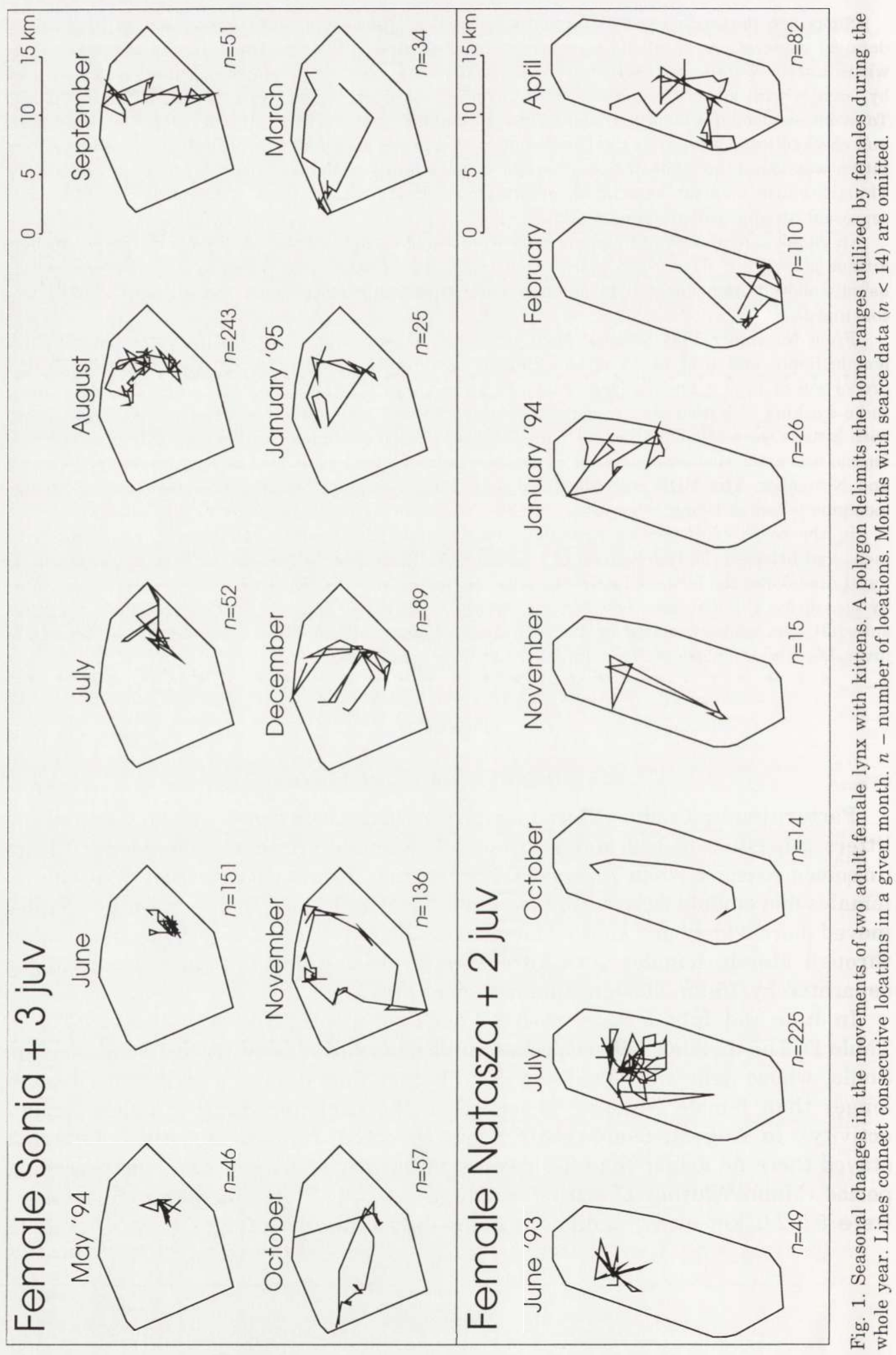




\section{Sonia +3 juv}
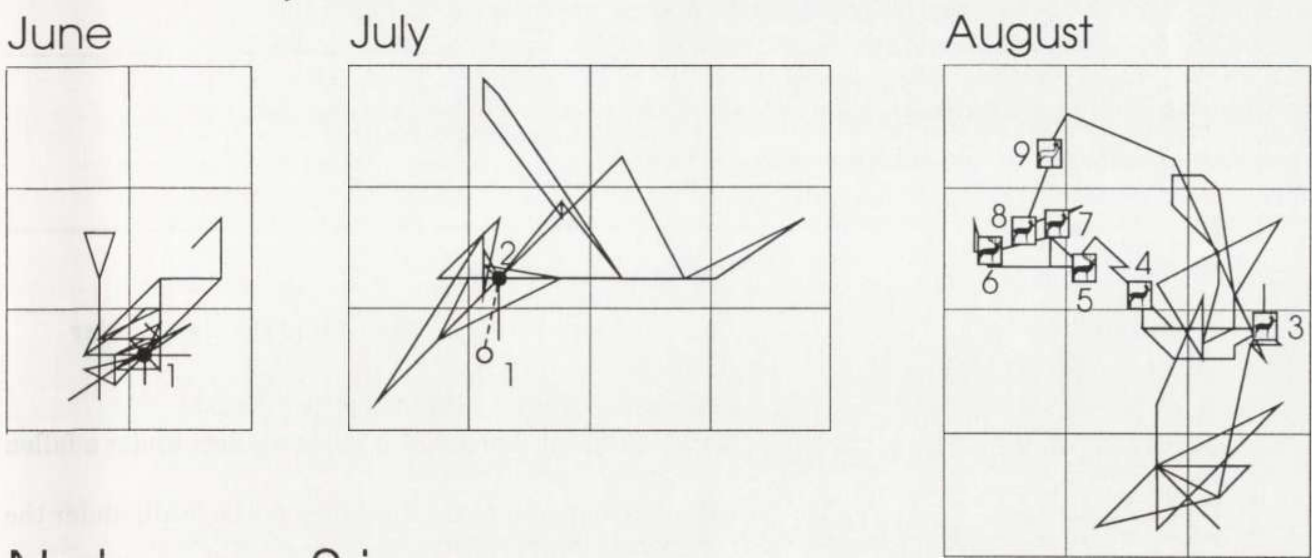

\section{Natasza + 2 juv}

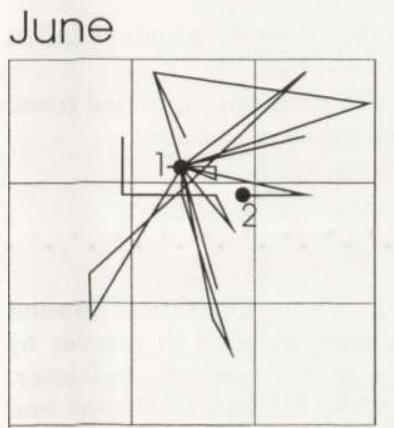

July

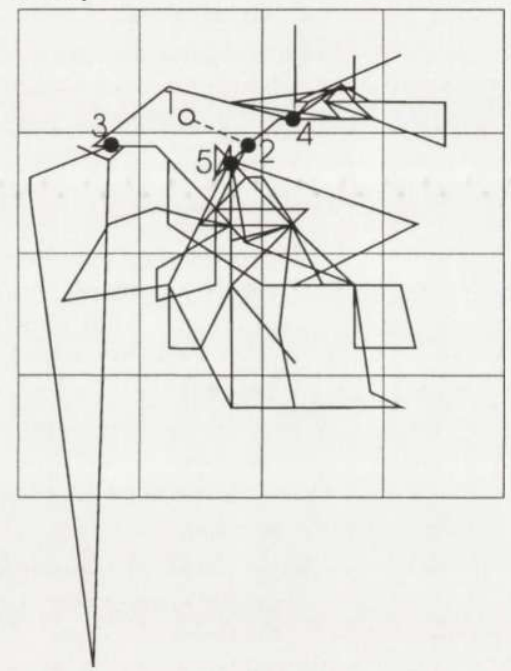

- den site

- former den position

1, 2, 3 consecutively used den sites

B dens with ungulate prey

[ suspected prey

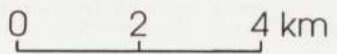

Fig. 2. Changes in the pattern of den utilization by two adult female lynx with kittens. Five 24-hour radio-tracking sessions of female Sonia are included in June and August (her movement in July was based on locations taken once a day). Three nightlong radio-tracking sessions in June and eight 24 -hour sessions in July are included in the case of female Natasza. Numbers of consecutive dens as in Table 1.

$p=0.2$ ) (Table 1, Fig. 2). In six of the seven recorded sites, ungulate prey killed by a female were found. The female and her kittens left each kill site soon after the prey had been entirely eaten.

The only one natal den was located on May 22, 1994 under the roots of a fallen spruce, and it contained a dead 7 day old, kitten. Vicinities of the dens utilized 
Table 1. Characteristics of consecutive dens utilized by two radio-collared female lynx during the early period of raising kittens. Consecutive numbers of dens are same as in Fig. 2.

\begin{tabular}{|c|c|c|c|}
\hline No. & $\begin{array}{c}\text { Time } \\
\text { of utilization } \\
\text { (number of } \\
\text { days) }\end{array}$ & $\begin{array}{c}\text { Straight-line } \\
\text { distance from } \\
\text { the previous } \\
\text { den }(\mathrm{km})\end{array}$ & Description of the den site \\
\hline \multicolumn{4}{|r|}{ Sonia +3 juv. } \\
\hline 1 & 7-26 June $1994(20)$ & $?$ & Place (not accessible) located behind the state border \\
\hline 2 & 28 June - 30 July (33) & 1.3 & As above \\
\hline 3 & $8-10$ August (2) & - & Pine-spruce thicket; a killed roe deer found \\
\hline 4 & $10-12$ August (2) & 2.0 & $\begin{array}{l}\text { Lime-oak-hornbeam stand; a killed roe deer under a fallen } \\
\text { spruce trunk }\end{array}$ \\
\hline 5 & $12-13$ August (2) & 1.1 & $\begin{array}{l}\text { Lime-oak-hornbeam stand; a killed red deer kill under the } \\
\text { roots of fallen spruce }\end{array}$ \\
\hline 6 & 14-16 August (3) & 1.5 & Lime-oak-hornbeam stand; a killed red deer \\
\hline 7 & 17-18 August (2) & 1.1 & $\begin{array}{l}\text { Lime-oak-hornbeam stand; a killed roe deer under a fallen } \\
\text { spruce trunk }\end{array}$ \\
\hline 8 & $19-20$ August (2) & 0.5 & $\begin{array}{l}\text { Lime-oak-hornbeam stand with numerous uprooted trees; } \\
\text { a killed roe deer under an uprooted spruce }\end{array}$ \\
\hline 9 & 21-23 August (3) & 1.5 & Lime-oak-hornbeam stand; a kill not found \\
\hline \multicolumn{4}{|c|}{ Natasza +2 juv. } \\
\hline 1 & 5-21 June 1993 (17) & $?$ & $\begin{array}{l}\text { Edge of the mixed forest and pine plantation; ground } \\
\text { covered with piles of tree roots fallen in masses by } \\
\text { hurricane wind and then pushed aside by bulldozer; } \\
\text { piles overgrown with thorny blackberry shrubs and } \\
\text { nettles }\end{array}$ \\
\hline 2 & 25 June - 4 July (11) & 1.1 & $\begin{array}{l}\text { Wet alderwood with stagnated water and numerous fallen } \\
\text { spruces }\end{array}$ \\
\hline 3 & 5-9 July (5) & 2.3 & $\begin{array}{l}\text { Wet alderwood with stagnated water and numerous fallen } \\
\text { spruces }\end{array}$ \\
\hline 4 & 14-18 July (5) & 3.3 & $\begin{array}{l}\text { Mixed forest with numerous uprooted spruces and oaks, } \\
\text { densely overgrown with thorny blackberry shrubs and } \\
\text { nettles }\end{array}$ \\
\hline 5 & 21-29 July (9) & 1.6 & $\begin{array}{l}\text { Wet alderwood with stagnant water and numerous fallen } \\
\text { spruces }\end{array}$ \\
\hline
\end{tabular}

by Natasza in June and July, were always barely accessible. They were densely covered with roots of fallen trees (mainly spruces), overgrown with nettles Urtica dioica and thorny blackberry Rubus sp. shrubs, or located in wet alderwoods with stagnant water (Table 1). In August, the kill sites where female Sonia stayed with her kittens were usually concealed under fallen trees, but the surroundings were not so densely covered with vegetation as those used in June and July by Natasza.

In June and July, females usually made short travels around the den (Fig. 2). They spent an average of $3 \mathrm{~h} 55 \mathrm{~min}(\mathrm{SD}=3 \mathrm{~h})$ with their kittens and left them 


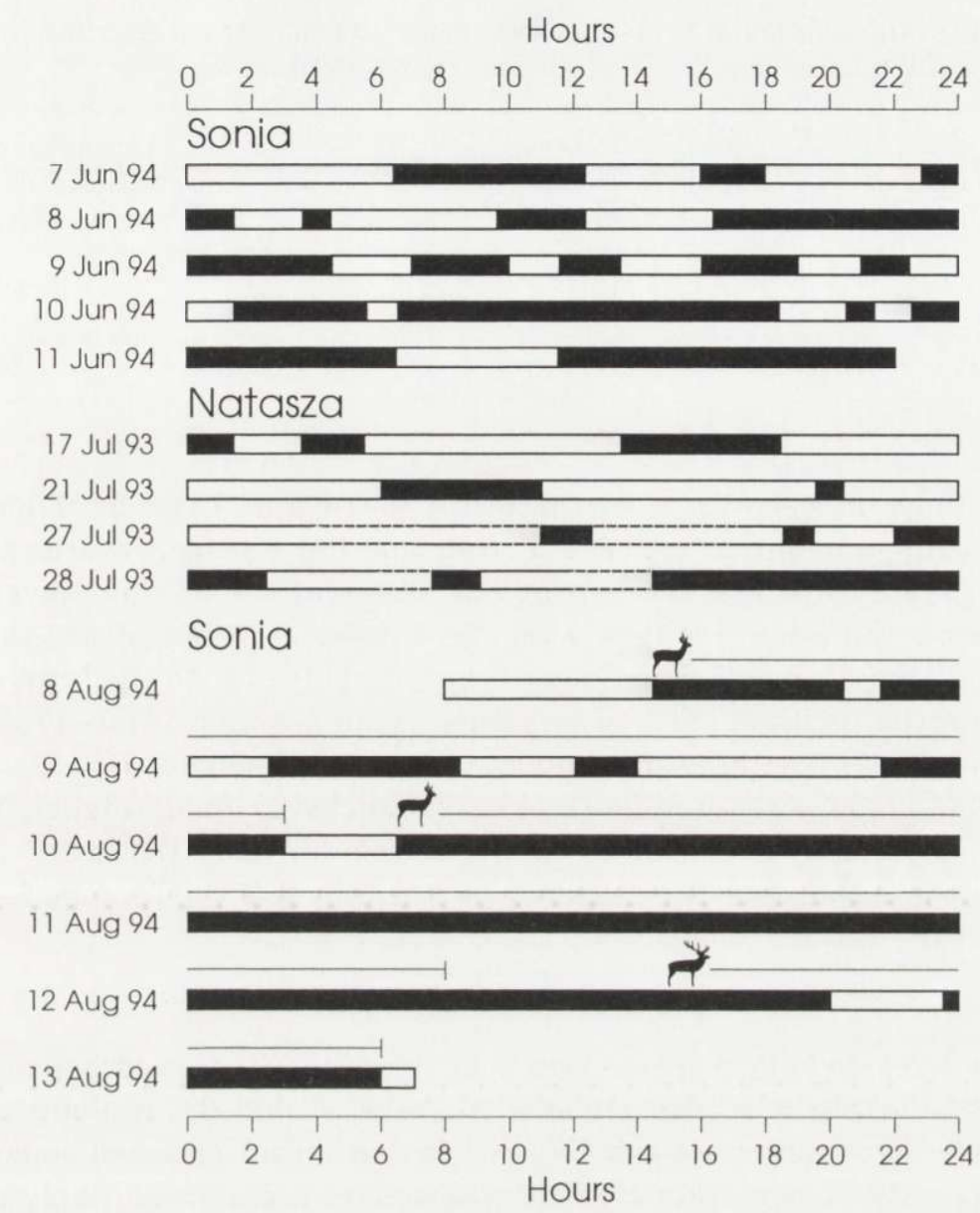

Fig. 3. Distribution of the time when females were in the den with kittens (black bars) and out of the den (white bars). In August, female Sonia stayed with the kittens near a killed roe deer or red deer (as marked by animal silhouettes). Broken lines mean lack of data.

for $4 \mathrm{~h} 20 \mathrm{~min}(\mathrm{SD}=3 \mathrm{~h}$ ) (Fig. 3). Thus, during this period, female lynx left their kittens 3 times per day. In one case, Natasza was located $8.5 \mathrm{~km}$ away from her suspected den (Fig. 2) for at least 21 hours. In August, the female Sonia usually moved from one den (kill site) to another, not returning to the former one (Fig. 2 ), which suggests that kittens accompanied the mother during the hunt. In this way, the amount of time family spent together increased to an average of $12 \mathrm{~h} 50$ $\min (\mathrm{SD}=21$ h $30 \mathrm{~min})$ (Fig. 3 ).

In November 1994 and January 1995 two kittens of female Sonia were fitted with radio-collars. They were radio-tracked simultaneously with their mother until early April. During that time female Sonia was usually near the kittens; the 
Table 2. Distance (in kilometers) between female Sonia and her kittens and the percentage of locations per $24 \mathrm{~h}$ when they were found together, $n$ - number of locations.

\begin{tabular}{|c|c|c|c|c|c|}
\hline & \multicolumn{3}{|c|}{ Distance (km) } & \multirow[t]{2}{*}{$n$} & \multirow{2}{*}{$\begin{array}{l}\text { Percentage of locations } \\
\text { when female and kittens } \\
\text { were together }\end{array}$} \\
\hline & $\bar{x}$ & $(\mathrm{SD})$ & range & & \\
\hline November & 0.3 & $(0.5)$ & $(0-2.0)$ & 52 & 83 \\
\hline December & 0.4 & (1.1) & $(0-4.8)$ & 16 & - \\
\hline January-March & 0.1 & $(0.3)$ & $(0-1.0)$ & 42 & 88 \\
\hline
\end{tabular}

average distance between them was from 0.1 to $0.4 \mathrm{~km}$ (Table 2). There was no gradual loosening of contact between mother and her kittens towards the end of the raising period. During 3 sessions of 24 -h observations (two in November and one in March), the female stayed with the kittens for $80 \%$ of time (Table 2). Analysis of all simultaneous fixes showed that she stayed with the kittens slightly longer during the daytime ( $81 \%$ of locations taken between $0700-1730 \mathrm{~h}$ ), than during the night ( $75 \%$ of locations taken between $1800-0630 \mathrm{~h}$ ).

The continuous sessions of radio-tracking conducted in June, August, November and February yielded 26 estimates of the minimum daily distances moved by females Sonia and Natasza. They covered $7.1 \mathrm{~km}$ daily $(\mathrm{SD}=4.7$, range $0-20.1 \mathrm{~km})$ regardless of the kittens' age $\left(R^{2}=0.04, n=26, p=0.3\right)$.

\section{Dispersal of subadult lynx}

Subadult lynx usually dispersed at 9-11 months of age and separated from their mothers between 10 March and 20 April (Table 3). In four cases, the subadults left their mothers suddenly, without an initial phase of separation. In one case, an early dispersal (at 8 months of age) of a male was likely caused by the shooting of his mother in the Belarussian part of the forest (A. N. Bunevich, pers. comm.).

Table 3. Time and distance of dispersal in six subadult Eurasian lynx from Białowieża Primeval Forest. Dispersal distance $=$ straight-line distance between the last localization in the natal range and the first localization in a subadult's own established home range. * - premature dispersal, see text.

\begin{tabular}{|c|c|c|c|c|c|}
\hline Lynx & Sex & Birth time & $\begin{array}{l}\text { Start of } \\
\text { dispersal }\end{array}$ & $\begin{array}{c}\text { Age at } \\
\text { dispersal } \\
\text { (in months) }\end{array}$ & $\begin{array}{c}\text { Dispersal } \\
\text { distance } \\
(\mathrm{km})\end{array}$ \\
\hline Mały & M & May-Jun 1991 & 21 Jan $1992^{*}$ & 8 & 129 \\
\hline Bazyliszek & M & May-Jun 1991 & 21-26 Mar 1992 & 10 & 11 \\
\hline Nikita & M & Early May 1994 & 12 Apr 1995 & 11 & 62 \\
\hline Dymitr & M & Early May 1994 & 20 Apr 1995 & 11 & 39 \\
\hline Zoja & $\mathrm{F}$ & May-Jun 1992 & $?$ & $?$ & 5 \\
\hline Lena & $\mathrm{F}$ & May-Jun 1994 & 10 Mar 1995 & $9-10$ & 9 \\
\hline
\end{tabular}




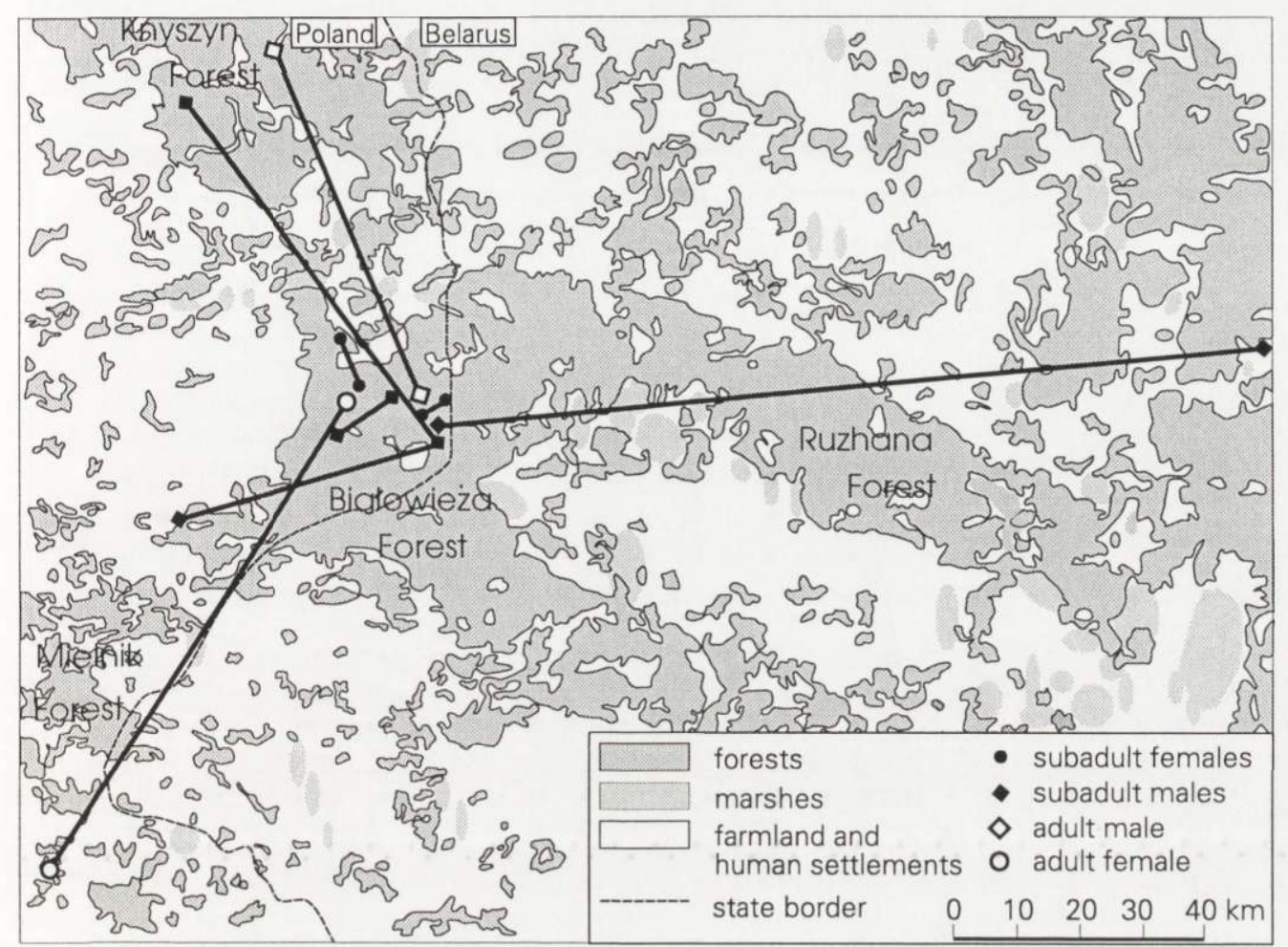

Fig. 4. Dispersal and emigration of lynx from Białowieża's population in 1992-1995. Lines connect the last radio-locations of subadults in their natal ranges and of adults in their territories with the last radio-locations when independent, or places where lynx were killed or observed.

Three males of the six radio-collared juvenile lynx left the area of BPF, whereas three others (two females, one male) remained in BPF at least as long as the radio-contact was maintained (Table 3, Fig. 4). Dispersal distances ranged from 5 to $129 \mathrm{~km}$. Two males, which moved long distances, accomplished these movements during the first two months of dispersal (April-May) (Fig. 5). The rate of dispersal was also the highest during this time $(20-36 \mathrm{~km}$ per month, for 3 subadult males). Afterwards, they stayed at about the same distance from the natal range (Fig. 5) and their dispersal rate decreased to $4.6-11.2 \mathrm{~km}$ per month. Two male siblings (Nikita and Dymitr) dispersed at different times (Table 3), however initially they moved in the same direction (Fig. 6). They stopped and began to occupy a more or less stable ranges $\left(16\right.$ and $39 \mathrm{~km}^{2}$ ) after 35 and 42 days. A male that reached the Knyszyn Forest apparently settled there, as indicated by subsequent observations of a radio-collared lynx 3 years later, April 1998 (Fig. 6) (L. Antoniuk pers. comm.). Lynx that did not leave BPF (male 


\section{Dispersal distance}
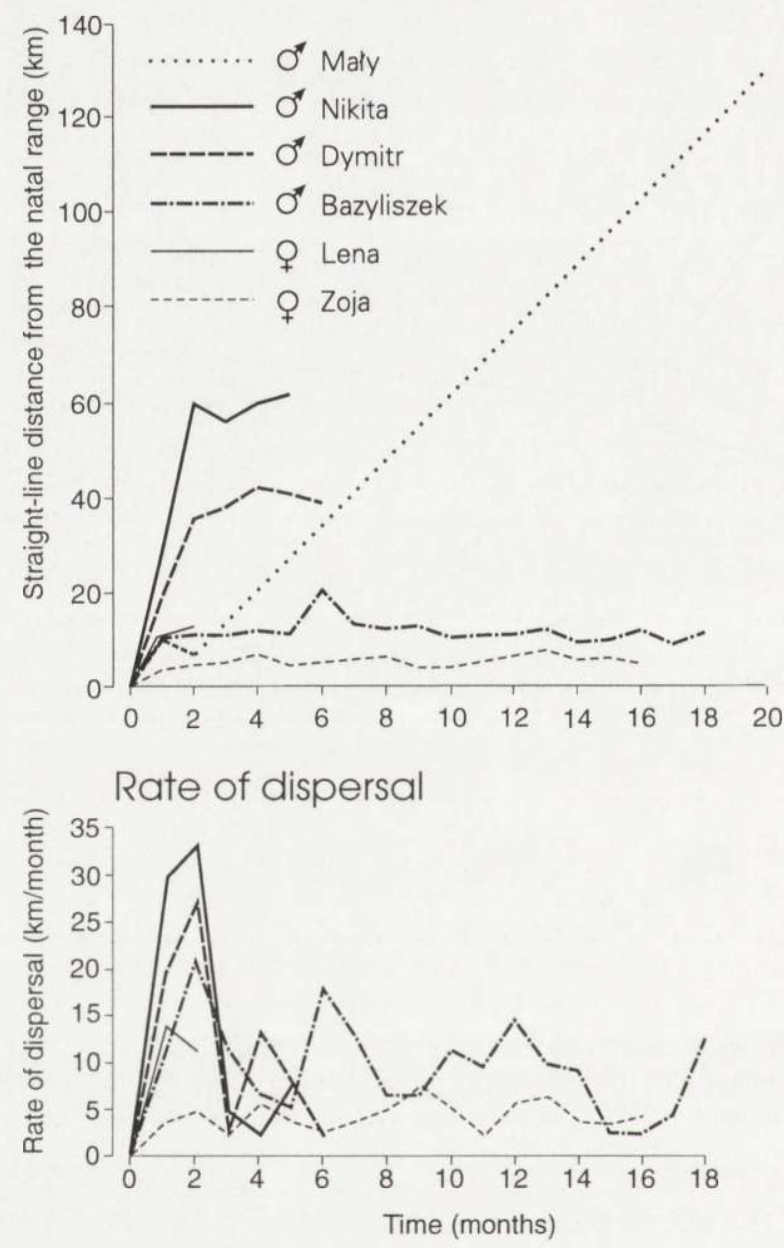

Fig. 5. The cumulative distance moved from the natal range by subadult lynx during the dispersal (upper panel), and the distance moved in consecutive months (rate of dispersal) during the same time (lower panel). In the case of male Mały, dots connect the end of radio-tracking and the time of his death 18 months later.

Bazyliszek and females Zoja and Lena) stayed throughout the study, at the same distance from their natal ranges (Fig. 5). Lena was radio-tracked for only 2 months after she separated from her mother, but her movements indicated that she might have started establishing a territory (Fig. 7).

During dispersal the lynx apparently followed the distribution of forested habitats. This was especially evident with two siblings which changed the directions of their routes after reaching the western limits of the forest (Fig. 6). Although the route of the male that dispersed to Belarus (where he was shot) is 


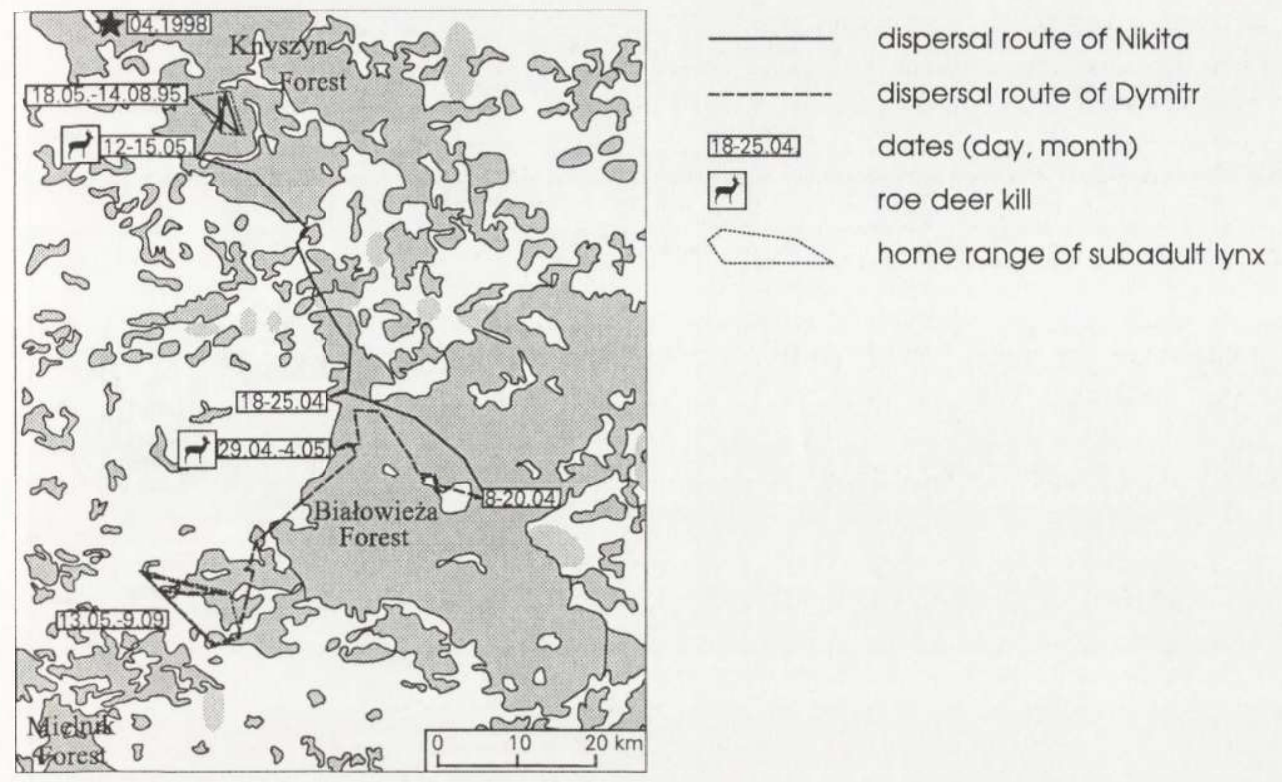

Fig. 6. Dispersal routes of two subadult siblings (males Nikita and Dymitr). Lines connect consecutive radio-locations. The asterisk shows the place, where a radio-collared lynx was observed in April 1998 (see text). See Fig. 4 for other explanations.

not known, it is probable that he could travel along the Rhuzhana Forest, a corridor connecting BPF with other large forests in the East (Fig. 4).

One of the subadults that stayed in BPF (male Bazyliszek) was radio-tracked for 21 months. After separation from his mother, he roamed widely for 6 months (26 March - 25 September 1992) in a large area of $254 \mathrm{~km}^{2}$. His range overlapped partly (17\%) with his natal range (Fig. 7). From October 1992 until November 1993, he occupied a smaller and more stable home range $\left(120 \mathrm{~km}^{2}\right)$ in the center of his formerly utilized area. In this period, his range was almost completely exclusive to that of his mother ( $2 \%$ overlap).

Among subadult females that did not leave BPF, Lena occupied a home range of $42 \mathrm{~km}^{2}$, which was near to, but not overlapping, that of her mother (Fig. 7). For female Zoja, it was not known if her home range $\left(51 \mathrm{~km}^{2}\right)$ overlapped that of her mother, however, during 20 months of radio-tracking, Zoja stayed less than 8 $\mathrm{km}$ from her capture site when she was still with her uncollared mother.

Subadult lynx were self-sufficient at independence as they were able to hunt even large mammals. Three roe deer Capreolus capreolus and one hare Lepus europaeus were found killed by four dispersers (6-30 days after separation). The early male disperser scavenged on a red deer Cervus elaphus carcass killed by hunters, and on remnants of ungulates killed by other lynx. 


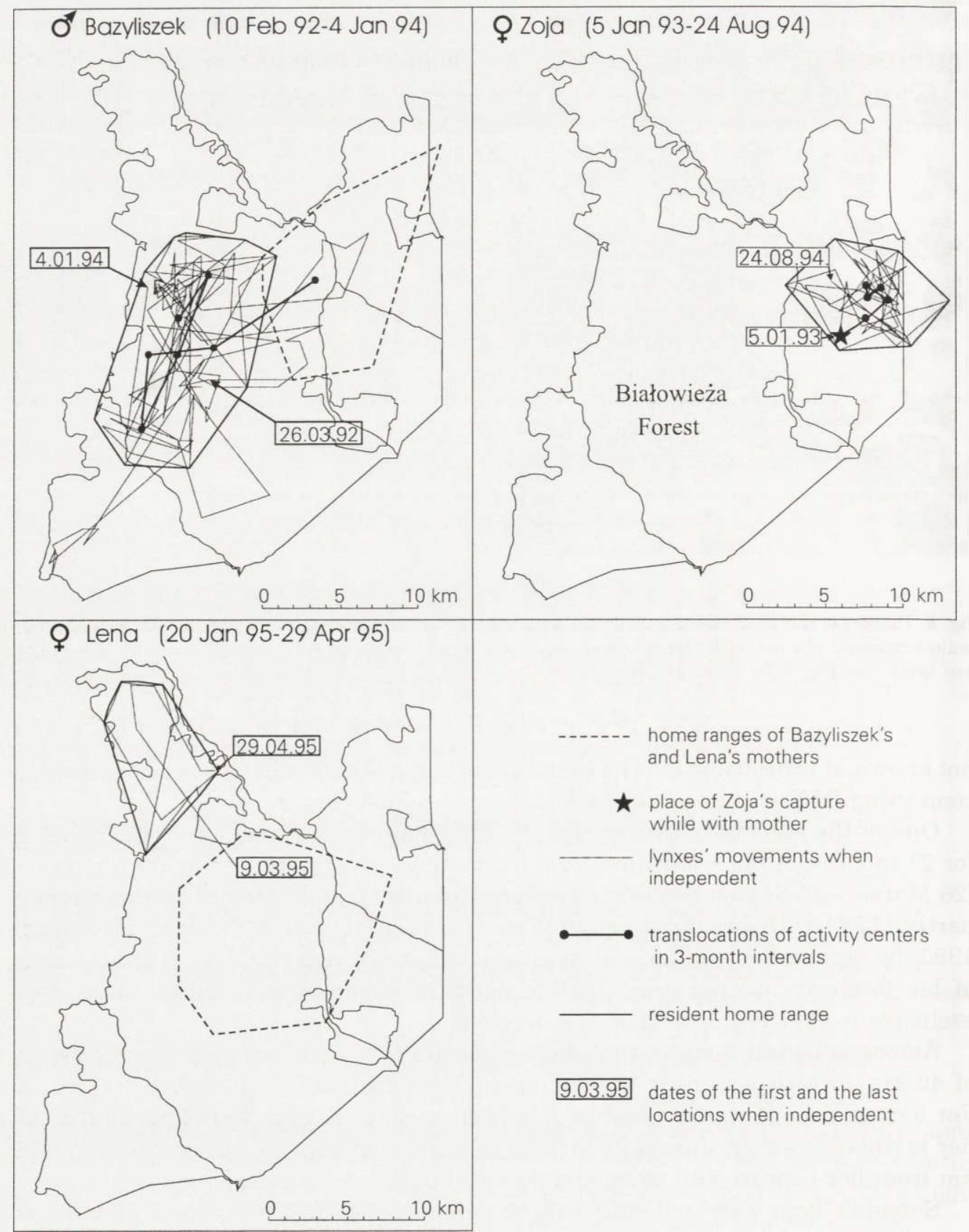

Fig. 7. The movements of three subadult lynx which settled in western part of BPF, close to their natal ranges. Home range of Zoja's mother was not known, however, during two following years, she occupied range near her capture site. She was still with her mother at the capture time, as recorded by snowtracking (the exact time of their separation is unknown). 


\section{Emigrations of adult lynx}

I recorded two cases of adult lynx that emigrated from BPF. Adult male Nikifor was captured in Białowieża National Park (the center of BPF) and located 19 times between January 25 and February 23, 1992 in the northern part of BPF. He was killed after contracting rabies in the Knyszyn Forest, $55 \mathrm{~km}$ from his place of capture, in late December 1993 (Fig. 5). Adult female Natasza was radio-tracked from February 1993 until March 1994 and produced 2 litters during that time (1 and 2 kittens). However, the second litter was lost in the winter 1994. During this time she was apparently trapped by (but escaped from) a poacher's steel jaw-trap as her tracks left drops of blood and lacked two toes. Natasza was not located in BPF after 28 March, 1994. In May 1994, a radio-collared lynx was observed 120 $\mathrm{km}$ south-west from BPF in the area of forest-farmland mosaic (Fig. 4). Because all other radio-collared lynx were still followed at that time or had been poached earlier, it must have been Natasza.

\section{Discussion}

The timing of lynx parturitions documented in BPF conform to the records from other parts of the species range (see Tumlison 1987 for review). Eurasian lynx in Norway showed somewhat later parturitions (29 May - 18 June; Kvam 1991) possibly due to higher latitudes.

In BPF, female lynx used only one or two dens when their kittens were 1-2 months old. In contrast, a female bobcat Lynx rufus in Florida, USA, used 8 dens during the first month of a kittens' life (Wassmer et al. 1988). This difference may be related to human activities. A female in BPF which changed dens frequently, occupied an area of timber harvest that was easily accessible to people and motor transportation. Other female that utilized dens longer, inhabited areas of BNP and the state border that were rarely visited by people.

Secure and well-camouflaged den sites are prerequisites to lynx kitten survival in the earlier period of their life because they are immobile and vulnerable to predation when female is living away from the den. Similarly, Laurenson (1994) reported that young cheetahs were less likely to be detected by predators when a female was hidden in the lair. Lynx kittens were usually left alone for no longer than 4 hours. Besides the need to nurse kittens, females stayed with them as long as possible to protect them. In contrast, lions (Panthera leo), which show communal care of cubs, were reported to spend 24 hours or more as far as $10 \mathrm{~km}$ from their cubs (Schaller 1972). A long absence (20-36 hours) from the den was also observed in a female leopard Panthera pardus when she guarded the kill against scavengers (Seidensticker 1977). Although in BPF large kills were not recorded in the earliest period of raising kittens, the need to guard prey would be less important than protecting kittens. The active protection of lynx kittens was more conspicuous beginning in August (kittens approximately 3 months old), when dens were more 
occasional and less hidden. During this time the family group was more often together. In Florida panthers Felis concolor coryi, the female spent less time at the den as the kittens grew (Maehr et al. 1989). This was, however, typical only for the first 33 days after parturition only.

Although the minimum daily distance moved by females did not change with the development of kittens, the pattern of female travel reflected increasing mobility of kittens and increasing food demands. In May-June, when kittens were nursed, the female moved around the den, hunting only for herself. In August, when meat became an important part of kitten diets (Guggisberg 1975), and kittens were able to accompany the mother during her hunt, the female traveled more widely and used the same den for no longer than 2-3 days. Similarly, in Swiss Alps, lynx kittens started to move with their mothers since the last week of August (Haller and Breitenmoser 1986). This behaviour differs considerably from that found in female bobcat, which used their entire home range in the first two months after parturition (Wassmer et al. 1988). The home range of female bobcats was $14.5 \mathrm{~km}^{2}$, ten times smaller than female lynx in BPF (Schmidt et al. 1997).

In BPF, lynx kittens accompanied their mother from August (3-4 months old) until family breakup, when they were $10-11$ months old. Family breakup coincides with the lynx mating season in February-March (Schmidt et al. 1997). This suggests that dispersal may be provoked by adult intolerance. Griffith and Fendley (1986) concluded the same for bobcats. The timing of lynx dispersal in BPF was similar to that of reintroduced lynx populations in Switzerland (Haller and Breitenmoser 1986 and Breitenmoser et al. 1993a).

Although sample sizes were limited, it appears that for lynx in Białowieża Forest, subadult males disperse for long distances, whereas females stay near their natal ranges. This conforms to the general rule found in other felids such as cougars Felis concolor (Maehr 1991, Laing and Lindzey 1993, Lindzey et al. 1988, 1994), leopards (Bailey 1993) and tigers Panthera tigris (Smith 1993). Breitenmoser et al. (1993b) predicted that dispersal of male Canada lynx Lynx canadensis is induced by decreasing density of their main prey snowshoe hares Lepus americanus. Lack of the male-biased dispersal in Canada lynx (Slough and Mowat 1996, Poole 1997) seems to support this prediction, but this is not the case in Białowieża Forest where the lynx rely primarily on ungulates (Jędrzejewski et al. 1996).

A $10-30 \%$ increase in adult lynx in BPF during the study, 1991-1994 (Jędrzejewski et al. 1996) and the fact that the farthest dispersal occurred in a year after recorded peak lynx density, suggest that dispersal was induced by the lack of local home range vacancies. However, because the range of male Bazyliszek overlapped nearly completely with that of an adult male (see Schmidt et al. 1997) shows that there must be other factors affecting dispersal. It is possible that adult males are more tolerant towards immature subadults, especially in a case of closely related individuals. Smith (1993) stated that dispersal in tigers was also influenced 
by the increased risk of mortality while searching for a new range. This may cause some subadult males to settle in the nearest vacancy regardless of the increased risk of inbreeding. Thus, dispersal is possibly a result of population density and the risk of increased mortality during far movements.

In other populations of lynx (Eurasian lynx in Switzerland, Haller and Breitenmoser 1986, Breitenmoser et al. 1993a; and Canada lynx, Poole 1995), both males and females dispersed for long distances but frequently stayed in their natal ranges for a few months after separation. Such an initial phase of independence (not recorded in this study) was also observed in leopards (Sunquist 1983), ocelots Felis pardalis (Ludlow and Sunquist 1987) and tigers (Smith 1993). Białowieża's lynx were not radio-tracked long enough to yield information about the time and distance between natal ranges and resident adult home ranges. It is, however, possible that at least one radio-collared lynx remained for three years in the area reached during initial dispersal (see Fig. 6). Dispersing cougars were reported to have used several transient home ranges, and to stay for a few months in each (Beier 1995).

Most solitary felids show strong site fidelity among resident adults and are considered territorial within a land tenure system (Hornocker 1969, Bailey 1974, 1993, Smith et al. 1987, Anderson 1988, Breitenmoser et al. 1993a, Schmidt et al. 1997). Emigration of adult individuals is common in Canada lynx, but occurs mainly during a decline of snowshoe hare densities (Slough and Mowat 1996). However, in adult Eurasian lynx, which does not rely on cyclic prey (Jędrzejewski et al. 1993, 1996), home range abandonment are more likely due to individual and intraspecific factors. Male Nikifor was killed because of rabies, but it was not certain if the illness had caused his emigration. Although behavioural changes in rabid animals have been observed only during the clinical stage that lasts no longer than a few days before death (U. Breitenmoser, pers. comm.), Nikifor, showed no fear of people and was occasionally observed by villagers for 6 months before his death. The emigration of female Natasza could have been caused by the loss of her kittens. Sunquist (1981) reported a similar situation for a female tiger that lost a litter before her range was taken over by her adult daughter.

The directions and distances of lynx dispersal were determined by the distribution of available habitat. Two males changed direction after reaching the western edge of the forest. Corridors within an agricultural mosaic were also important to dispersing lynx and may have helped this peripheral population to survive. Clearly, open farmland constituted a barrier for lynx. It make impossible for dispersing lynx to reach distant suitable habitats. The recorded distances of dispersal and emigration reveal that Białowieża's population of lynx form a regional metapopulation (through exchange of individuals) with other populations of lynx in a range which stretches over at least $20.000 \mathrm{~km}^{2}$.

Acknowledgements: This work is a part of the project on lynx ecology conducted by the author, together with Dr W. Jędrzejewski and Dr H. Okarma. I am grateful to them for their help in capturing lynx, radio-tracking and all kinds of help and support with field work. R. Kowalczyk, S. Snieżko, 
D. Bender, H. Holzapfel and P. Bielecki participated in the continuous sessions of radio-tracking. Information about the lynx shot in Belarus was provided by Mr A. N. Bunevich (State National Park Belovezhskaya Pushcha, Belarus). Data on lynx sightings in the forest near Biała Podlaska were kindly provided by the Director of Nature Conservation Department in Biała Podlaska, Mr J. Szostakiewicz. I am greatly indebted to Dr B. Jedrzejewska for her time spent to improve an earlier draft of this paper. I am also grateful to Dr D. S. Maehr and three anonymous referees for their valuable comments on the manuscript and correcting the English usage. The study was financed by grant KBN 6 P20503405.

\section{References}

Anderson E. M. 1988. Effects of male removal on spatial distribution of bobcats. Journal of Mammalogy 69: 637-641.

Bailey T. N. 1974. Social organization in a bobcat population. The Journal of Wildlife Management. 38: $435-446$.

Bailey T. N. 1993. The African leopard. Ecology and behaviour of a solitary felid. Columbia University Press, New York: 1-429.

Beier P. 1995. Dispersal of juvenile cougars in fragmented habitat. The Journal of Wildlife Management 59: 228-237.

Böer M., Śmielowski J. and Tyrala P. 1995. Reintroduction of the European lynx (Lynx lynx) to the Kampinoski Nationalpark/Poland - a field experiment with zooborn individuals. Part II: release phase: procedures, and activities of lynxes during the first year after. Der Zoologische Garten 65: $333-342$.

Breitenmoser U. and Breitenmoser-Würsten Ch. 1990. Status, conservation needs and reintroduction of the lynx $(\operatorname{Lyn} x \operatorname{lyn} x)$ in Europe. Council of Europe. Nature and Environment Series, Strasbourgh: $1-47$.

Breitenmoser U., Kaczensky P., Dötterer M., Breitenmoser-Würsten Ch., Capt S., Bernhart F. and Liberek M. 1993a. Spatial organization and recruitment of lynx (Lynx lynx) in a re-introduced population in the Swiss Jura Mountains. Journal of Zoology, London 231: 449-464.

Breitenmoser U., Slough B. G. and Breitenmoser-Würsten Ch. 1993b. Predators of cyclic prey: is the Canada lynx victim or profiteer of the snowshoe hare cycle? Oikos 66: 551-554.

Faliński J. B. 1986. Vegetation dynamics in temperate lowland primeval forest. Ecological studies in Białowieża forest. Dr W. Junk Publishers, Dordrecht, Geobotany 8: 1-537.

Griffith M. A. and Fendley T. T. 1986. Pre and post dispersal movement behaviour of subadult bobcats on the Savannah River Plant. [In: Cats of the world: biology, conservation, and management. S. D. Miller and D. D. Everett, eds]. National Wildlife Federation, Washington D.C: 277-289.

Guggisberg C. A. W. 1975. Wild cats of the world. Taplinger Publishers Co., New York: 1-328

Haller H. and Breitenmoser U. 1986. Zur Raumorganisation der in den Schweizer Alpen wiederangesiedelten Population des Luchses (Lynx lynx). Zeitschrift für Säugetierkunde. 51: 289-311.

Hornocker M. G. 1969. Winter teritoriality in mountain lions. The Journal of Wildlife Management 33: $457-464$.

Jackson P. 1994. Europe's introduced lynx in peril? Cat News 20: 19.

Jędrzejewski W., Schmidt K., Miłkowski L., Jędrzejewska B. and Okarma H. 1993. Foraging by lynx and its role in ungulate mortality: the local (Białowieża Forest) and the Palearctic viewpoints. Acta Theriologica 38: 385-403.

Jędrzejewski W., Jędrzejewska B., Okarma H., Schmidt K., Bunevich A., and Miłkowski L 1996. Population dynamics (1869-1994), demography, and home ranges of the lynx in Białowieża Primeval Forest (Poland and Belaruss). Ecography 19: 122-138.

Kvam T. 1991. Reproduction of the European lynx, Lynx lynx. Zeitshrift für Säugetierkurde 56: $146-158$.

Kitchener A. 1991. The natural history of wild cats. Comstock Publishing Associates. Ithaca, New York: $1-280$. 
Laing S. P. and Lindzey F. G. 1993. Patterns of replacement of resident cougars in southern Utah. Journal of Mammalogy 74: 1056-1058.

Laurenson M. K. 1994. High juvenile mortality in cheetahs (Acinonyx jubatus) and its consequences for maternal care. Journal of Zoology, London 234: 387-408.

Lindzey F. G., Ackerman B. B., Barnhurst D. and Hemker T. P. 1988. Survival rates of mountain lions in Southern Utah. The Journal of Wildlife Management 52: 664-667.

Lindzey F. G., Van Sickle W. D., Ackerman B. B., Barnhurst D., Hemker T. P and Laing S. P. 1994. Cougar population dynamics in Southern Utah. The Journal of Wildlife Management 58: 619-624.

Ludlow M. E. and Sunquist M. E. 1987. Ecology and behaviour of ocelots in Venezuela. National Geographic Research 3: 447-461.

Maehr D. S., Land E. D., Roof J. C. and McCown J. W. 1989. Early maternal behaviour in the Florida panther (Felis concolor coryi). The American Midland Naturalist 122: 34-43.

Maehr D. S., Land E. D. and Roof J. C. 1991. Social ecology of Florida panthers. National Geographic Research and Exploration 7: 414-431.

Poole K. G. 1995. Spatial organization of a lynx population. Canadian Journal of Zoology 73: 632-641.

Poole K. G. 1997. Dispersal patterns of lynx in the Northwest Territories. The Journal of Wildlife Management 61: 497-505.

Schaller G. B. 1972. The Serengeti lion: A study of predator-prey relations. University of Chicago Press, Chicago: 1-480.

Schmidt K., Jędrzejewski W. and Okarma H. 1997. Spatial organization and social relations in the Eurasian lynx population in Białowieża Primeval Forest, Poland. Acta Theriologica 42: 289-312.

Seidensticker J. 1977. Notes on early maternal behaviour of the leopard. Mammalia 41: 111-113.

Slough B. G. and Mowat G. 1996. Lynx population dynamics in an untrapped refugium. The Journal of Wildlife Management 60: 946-961.

Smith J. L. D. 1993. The role of dispersal in structuring the Chitwan tiger population. Behaviour 124: $165-195$.

Smith J. L. D., McDougal C. W. and Sunquist M. E. 1987. Female land tenure system in tigers. [In: Tigers of the world. R. L. Tilson and U. S. Seal, eds]. Noyes Publications, New Jersey: 97-109.

Sokolov V. E., Naidenko S. V. and Serbenyuk M. A. 1994. Specific fights of young lynxes (Felis lynx, Carnivora, Felidae). Zoologicheskiï Zhurnal 73: 132-137. [In Russian with English summary]

Sunquist M. E. 1981. The social organization of tigers (Panthera tigris) in Royal Chitawan National Park, Nepal. Smithsonian Contributions to Zoology 336: 1-98.

Sunquist M. 1983. Dispersal of three radiotagged leopards. Journal of Mammalogy 64: 337-341.

Tumlison R. 1987. Felis lynx. Mammalian Species 269: 1-9.

Wassmer D. A., Guenther D. D. and Layne J. N. 1988. Ecology of the bobcat in South-Central Florida. Bulletin of the Florida State Museum, Biological Sciences 33: 159-228.

Zaręba R. 1986. [Woodlands and forests of Poland]. Państwowe Wydawnictwo Rolnicze i Leśne, Warszawa: 1-204. [In Polish]

Received 5 May 1998, accepted 9 October 1998. 
Appendix 1. Subadults, reproducing females and emigrating adult lynx radio-tracked in Białowieża Primeval Forest in 1991-1995. ${ }^{a}$ lynx radio-tracked during at least one session of 24-hours tracking. b siblings from a litter of 3 kittens born in 1994 by female Sonia. ${ }^{c}$ offspring (born in 1994) of a female Diana.

\begin{tabular}{|c|c|c|c|c|}
\hline Lynx's name & Age/sex & $\begin{array}{l}\text { Duration of } \\
\text { radio-tracking }\end{array}$ & $\begin{array}{l}\text { Number of } \\
\text { records }\end{array}$ & Fate \\
\hline Sonia $^{\mathrm{a}}$ & Ad F & 30 Jan $1993-8$ Apr 1995 & 461 & Collar failure \\
\hline Natasza $^{a}$ & Ad F & 3 Feb $1993-28$ Mar 1994 & 173 & Emigrated, contact lost \\
\hline Nikifor & Ad M & 25 Jan - 23 Feb 1993 & 15 & Killed as rabid \\
\hline Tamara $^{\mathrm{a}}$ & Ad F & $29 \mathrm{Mar}-22$ Aug 1994 & 117 & Died \\
\hline Mały & Subad M & 11 Dec 1991 - 21 Jan 1992 & 18 & Shot \\
\hline Bazyliszek $^{\mathrm{a}}$ & Subad M & 10 Feb 1992 - 4 Jan 1994 & 177 & Poached \\
\hline Zoja & Subad F & 5 Jan 1993 - 24 Aug 1994 & 59 & Collar failure \\
\hline Nikita $^{\text {ab }}$ & Subad M & 16 Nov $1994-14$ Aug 1995 & 126 & Dispersed, contact lost \\
\hline Lena $^{\text {ac }}$ & Subad F & 20 Jan - 29 Apr 1995 & 55 & Collar failure \\
\hline Dymitr $^{\mathrm{ab}}$ & Subad M & 24 Jan - 9 Sep 1995 & 75 & Dispersed, contact lost \\
\hline Diana $^{a}$ & Ad F & 4 Mar-8 Aug 1995 & 112 & Collar failure \\
\hline
\end{tabular}

